\title{
Uncommon Rh Phenotypes in a Cross Section of Nigerian Antenatal Women: Implications for Molecular Genotyping of Blood Groups
}

Zaccheaus A Jeremiah ${ }^{1 *}$, Amos A Biribo ${ }^{2}$, Teddy C Adias ${ }^{3}$ and Emmanuel K Uko ${ }^{4}$

${ }^{1}$ Haematology and Blood Transfusion Science Unit, Department of Medical Laboratory Science, College of Health Sciences, Niger Delta University, Wilberforce Island, Nigeria

${ }^{2}$ Naval Base Clinic, Borokiri, Port Harcourt, Nigeria

${ }^{3}$ College of Health Technology, Otuogidi, Ogbia, Nigeria

${ }^{4}$ Department of Medical Laboratory Science, University of Calabar, Calabar, Nigeria

\author{
Abstract \\ Background: This study aimed to determine the frequency of rare blood group antigens among pregnant \\ women in Port Harcourt Metropolis.
}

Methods: The frequencies of Rh antigens and phenotypes of the pregnant women in Port Harcourt Metropolis, Nigeria, were determined, using standard serologic techniques.

Results: Of the 374 pregnant women studied, the frequencies of the Rh antigens within the population were D $(89.0 \%)$, c $(82.0 \%)$, e $(54.0 \%), C(24.3 \%)$, E (20.1\%). The frequencies of the Rh antithetical antigens were DD/Dd (91.2 \%), Cc (19,5\%), cc (84.5\%), Ee (13.9\%), ee (54.3\%), CC $(25.1 \%)$, EE $(19.8 \%)$ and dd $(10.4 \%)$. Seven $(1.9 \%)$ were found to be $\mathrm{Rh}_{\text {null, }}$, sixteen $(4.3 \%)$ were found to be $\mathrm{D}$-- or exalted $\mathrm{D}$. Phenotypes without $\mathrm{RhD}$ reactivity were -C- $(2.9 \%)$, - Cc $(0.3 \%)$, - C- $(0.3 \%)$, - Ee $(0.5 \%)$ and $-\mathrm{E}-(0.3 \%)$. The most frequently occurring Rh phenotype was Dccee with a frequency of $(25.8 \%)$. RhD-ve was found to be significantly associated with HDN outcome ( $2=6.605$ and $\mathrm{P}=0.01)$.

Conclusion: We concluded that: 1) There is the presence of uncommon Rh phenotypes in our population. 2) $\mathrm{Rh}_{\text {nul }}$ exists in this study population of which similar studies have not been reported in Nigeria. 3) There is need to conduct studies in other parts of Nigeria in order to compare the frequencies of these rare blood groups in Nigerian population. 4) Molecular studies to establish reasons for deletion and $\mathrm{Rh}_{\text {null }}$ phenotypes among Nigerian and Africans in general are hereby advocated.

Keywords: Rh phenotype; Blood groups; RhD negative; RhD positive

\section{Introduction}

The Rh blood group has been reported to be the most complex and highly polymorphic of all the blood group systems [1]. Apart from the importance of the $\mathrm{Rh}$ antigens in blood transfusion and Haemolytic Disease of the New born $(\mathrm{HDN})^{2}$. Rh proteins are involved in transporting ammonium across the RBC membrane [2]. It follows that RBCs which lack Rh antigens will have abnormal shape, increased osmotic fragility and shortened lifespan, resulting in haemolytic anaemia that is usually mild in nature [1]. These patients are also at risk of adverse transfusion reactions because they may produce antibodies against several of the Rh antigens. The $\mathrm{D}$ antigen contains over 30 epitopes. Variations of the D phenotype arise when these epitopes are weakly expressed or missing resulting in uncommon phenotypes which are usually very rare. The frequencies of these uncommon $\mathrm{Rh}$ phenotypes are yet to be reported in this part of the globe. In this paper, we report some uncommon $\mathrm{Rh}$ phenotypes which we encountered during our study of Rh phenotyping of antenatal women.

\section{Materials and Methods}

\section{Subjects}

A total of 374 pregnant women of various ages and ethnic background who were attending antenatal clinics in Braithwaite Memorial Specialist Hospital (BMSH) and Churchill Primary Health Care Centre, Port Harcourt City were recruited into the study. The study population consisted of eight ethnic nationalities: Ijaw, Ibo, Ibibio, Ikwerre, Yoruba, Ogoni, Hausa, Ekpeye and others who could not define their nationalities. The 374 pregnant women were in their various trimesters, attending antenatal clinics in both hospitals within a period of 6 months.

\section{Study design}

A prospective cross-sectional design was used in this study. Samples were collected randomly after obtaining informed consents from the study participants. The study received institutional ethical approval from the Braithwaite Memorial Specialist Hospital (BMSH), Port Harcourt, Nigeria.

\section{Blood collection}

Two milliliters $(2 \mathrm{ml})$ of venous blood was collected from each of the 374 pregnant women through veni puncture using the antecubital vein into an Ethylenediamine Tetracetic Acid (EDTA) of $1.5 \mathrm{ml}$ concentration. Samples that were not phenotyped the same day were archived at $2-8^{\circ} \mathrm{C}$ till the following day.

\section{Procedures}

The test procedure was based on the principle of haemagglutination

*Corresponding author: Zaccheaus A Jeremiah, Haematology and Blood Transfusion Science Unit, Department of Medical Laboratory Science, College of Health Sciences, Niger Delta University, Wilberforce Island, E-mail: za.jeremiah@ mail.ndu.edu.ng

Received July 23, 2012; Accepted October 01, 2012; Published October 03 2012

Citation: Jeremiah ZA, Biribo AA, Adias TC, Uko EK (2012) Uncommon Rh Phenotypes in a Cross Section of Nigerian Antenatal Women: Implications for Molecular Genotyping of Blood Groups. J Blood Disord Transfus S10:001. doi:10.4172/2155-9864.S10-001

Copyright: (c) 2012 Jeremiah ZA, et al. This is an open-access article distributed under the terms of the Creative Commons Attribution License, which permits unrestricted use, distribution, and reproduction in any medium, provided the original author and source are credited. 
Citation: Jeremiah ZA, Biribo AA, Adias TC, Uko EK (2012) Uncommon Rh Phenotypes in a Cross Section of Nigerian Antenatal Women: Implications for Molecular Genotyping of Blood Groups. J Blood Disord Transfus S10:001. doi:10.4172/2155-9864.S10-001

Page 2 of 4

where the red cells possessing the specific antigen will agglutinate when tested with the corresponding reagent (antibody).

\section{Rhesus (Rh.) Phenotyping}

RBCs were phenotyped for D, C, E, c, e, antigens according to standard serologic protocols with $1 \mathrm{gG} / \mathrm{lgM}$ anti-D (11167/2), $1 \mathrm{gM}$ MoAbs specific for C. (AC2329), c (Ac2368), E (ME2031) and e (Ae3469) (BIOTEC; IPSWICH, SUFFOLD, UK). Eight tubes were arranged in a row and labeled anti-D, C, c, E, e, and autocontrols for each of 374 patients. Two drops of antisera and one drop of a $5 \%$ washed RBC suspension were added to each tube. This was followed by incubation at $37^{\circ} \mathrm{C}$ for 30 minutes. At the end of 30 minutes, the tubes were centrifuged and the agglutination was read macroscopically. All of the negative results of Rhesus (D) were confirmed microscopically; Albumin and Anti-Human Globulin (AHG) tests were used as control and for weak D determination. To determine the presence of weak D antigen, one drop of anti-human globulin reagent and one drop of RBC suspension were added to a labeled test tube and incubated at $37^{\circ} \mathrm{C}$ for 30 minutes.

\section{Statistical method}

SPSS version 16 for window (Chicago Illinois) was used for frequency distribution for blood groups, Pearson Chi-square test to test the association of jaundice with blood groups.

\section{Results}

Table 1 shows demographic characteristics of the study participants. The Ijaw ethnic group was found to have the highest frequency $(30.5 \%)$, follows by Ibo 99 (26.5\%), Ikwerre 48 (12.8\%), others 37 (9.9\%), Ibibio 30 (8.0\%), Yoruba 16 (4.3\%), Ogoni 14 (3.7\%), Ekpeye 13 (3.5\%), and Hausa $3(0.8 \%)$. The frequencies of the age range are also shown in the table. The age range of $25-29$ yrs was found to have the highest frequency 148 (39.6\%), followed by 30-34 yrs 135 (36.1\%), 20-24 yrs 42 (11.27\%), $35-39$ yrs 38 (10.2\%), $15-19$ yrs 6(1.6\%), and 40 yrs and above 5 (1.3\%), another is the frequency of trimester. The second trimester was found to have the highest frequency, 221 (59.1\%), followed by third trimester $110(29.4 \%)$, and first trimester 43 (11.5\%). The frequency distribution

\begin{tabular}{|l|l|l|}
\hline Ethnic Groups & Number & Percent \\
\hline Ekpeye & 13 & 3.5 \\
\hline Hausa & 3 & .8 \\
\hline Ibibio & 30 & 8.0 \\
\hline Ibo & 99 & 26.5 \\
\hline Ijaw & 114 & 30.5 \\
\hline Ikwerre & 48 & 12.8 \\
\hline Ogoni & 14 & 3.7 \\
\hline Yoruba & 16 & 4.3 \\
\hline Others & 37 & 9.9 \\
\hline Age Range & & \\
\hline $15-19$ Years & 6 & 1.6 \\
\hline $20-24$ Years & 42 & 11.2 \\
\hline $25-29$ Years & 148 & 39.6 \\
\hline $30-34$ Years & 135 & 36.1 \\
\hline $35-39$ Years & 38 & 10.2 \\
\hline 40 Years and above & 5 & 1.3 \\
\hline Trimester & & \\
\hline First & 43 & 11.5 \\
\hline Second & 221 & 59.1 \\
\hline Third & 110 & 29.4 \\
\hline & & \\
\hline
\end{tabular}

Table 1: Demographic Characteristics of the Study Participants. of $\mathrm{Rh}$ antigens is shown in table 2 . The highest frequency among $\mathrm{Rh}$ antigens was found to be D (89.0\%) followed by c (82.4\%), e (54.0\%), $\mathrm{C}(24.3 \%), \mathrm{E}(20.1 \%)$ and $\mathrm{D}^{\mathrm{u}}(0.0 \%)$. Rh phenotype frequencies in the population are shown in table 3 . Twenty five phenotypes were found to occur in the population, the most common being Dccee (25.8\%), and $\mathrm{dccEe}(0.5 \%)$, and DCCEe $(0.3 \%)$ were the rarest phenotypes in the population. Out of the twenty five phenotypes in the population, there were $\mathrm{D}-(6.5 \%),--\mathrm{D}, \mathrm{D}--,--\mathrm{E}(0.8 \%)$ and $\mathrm{Rh}_{\text {null }}(1.9 \%)$. The frequency of distribution of neonatal jaundice among blood groups, are shown in table 4 . Neonatal jaundice occurred more frequently among the $\mathrm{RhD}$ group (22.9\%) while it least occurred among C (7.7\%).

Table 5 shows the antithetical antigen frequencies within the study population. The DD/Dd was found to occur more frequently (91.2\%), followed by cc (84.5\%), ee (54.3\%), CC (25.1\%), EE (19.8\%), Cc (19.5\%), Ee (13.9\%) and dd (10.4\%) respectively.

\section{Discussion}

Within the South-South region of Nigeria, Rhesus phenotypes in the general population has been studied and reported in Port Harcourt

\begin{tabular}{|l|l|l|}
\hline Blood group Rh & Number & Percentage (\%) \\
\hline D & 333 & 89.0 \\
\hline C & 91 & 24.3 \\
\hline C & 308 & 82.4 \\
\hline E & 75 & 20.1 \\
\hline e & 202 & 54.0 \\
\hline D $^{u}$ & 0 & 0.0 \\
\hline
\end{tabular}

Table 2: Distribution of Blood Group in the Study Population.

\begin{tabular}{|c|c|c|c|c|}
\hline \multicolumn{3}{|c|}{ Fisher - Race Probable Rh Phenotype } & \multirow[t]{2}{*}{ Number } & \multirow{2}{*}{$\begin{array}{c}\text { Percentage } \\
(\%)\end{array}$} \\
\hline $\begin{array}{l}\text { Short } \\
\text { Notation }\end{array}$ & $\begin{array}{c}\text { Gene } \\
\text { Complex }\end{array}$ & Antigen & & \\
\hline- & $\mathrm{Rh}_{\text {null }}(-1-)$ & - (Rhnull) & 7 & 1.9 \\
\hline $\mathrm{R}$ & $-\mathrm{C}-$ & c & 11 & 2.9 \\
\hline$r^{1}$ & $-\mathrm{Cc}$ & $\mathrm{C}, \mathrm{C}$ & 1 & 0.3 \\
\hline $\mathrm{r}^{1}$ & $-\mathrm{C}-$ & $\mathrm{C}$ & 1 & 0.3 \\
\hline $\mathrm{R}_{0}$ & Dc- & $\mathrm{D}, \mathrm{C}$ & 70 & 18.6 \\
\hline $\mathrm{R}_{1}$ & DCc & $\mathrm{D}, \mathrm{C}, \mathrm{C}$ & 30 & 8.0 \\
\hline $\mathrm{R}_{1}$ & DC- & $\mathrm{D}, \mathrm{C}$ & 13 & 3.5 \\
\hline $\mathrm{R}$ & dce & $\mathrm{c}, \mathrm{e}$ & 6 & 1.6 \\
\hline r" & cEe & $\mathrm{c}, \mathrm{E}, \mathrm{e}$ & 1 & 0.3 \\
\hline$r^{\prime}$ & Cce & $\mathrm{C}, \mathrm{C}, \mathrm{e}$ & 2 & 0.5 \\
\hline r" & CcEe & $\mathrm{C}, \mathrm{c}, \mathrm{E}, \mathrm{e}$ & 1 & 0.3 \\
\hline $\mathrm{R}_{0}$ & Dce & $\mathrm{D}, \mathrm{c}, \mathrm{e}$ & 97 & 25.8 \\
\hline $\mathrm{R}_{2}$ & DcEe & $\mathrm{D}, \mathrm{c}, \mathrm{E}, \mathrm{e}$ & 40 & 10.7 \\
\hline $\mathrm{R}_{2}$ & DcE & $\mathrm{D}, \mathrm{c}, \mathrm{E}$ & 15 & 4.0 \\
\hline $\mathrm{R}_{1}$ & DCce & $\mathrm{D}, \mathrm{C}, \mathrm{C}, \mathrm{e}$ & 28 & 7.5 \\
\hline $\mathrm{R}_{2}$ & DCcEe & $\mathrm{D}, \mathrm{C}, \mathrm{c}, \mathrm{E}, \mathrm{e}$ & 9 & 2.5 \\
\hline $\mathrm{R}_{2}$ & DCcE & $\mathrm{D}, \mathrm{C}, \mathrm{c}, \mathrm{E}$ & 2 & 0.5 \\
\hline $\mathrm{R}_{1}$ & $\mathrm{DCe}$ & $\mathrm{D}, \mathrm{C}, \mathrm{e}$ & 3 & 0.8 \\
\hline $\mathrm{R}_{2}$ & DCEe & $\mathrm{D}, \mathrm{C}, \mathrm{E}, \mathrm{e}$ & 1 & 0.3 \\
\hline $\mathrm{R}_{2}$ & DCE & $\mathrm{D}, \mathrm{C}, \mathrm{E}$ & 3 & 0.8 \\
\hline $\mathrm{R}_{0}$ & -D- & D & 16 & 4.3 \\
\hline r" & -Ee & $\mathrm{E}, \mathrm{e}$ & 2 & 0.5 \\
\hline$R_{0}$ & $-\mathrm{De}$ & $\mathrm{D}, \mathrm{e}$ & 13 & 3.5 \\
\hline $\mathrm{R}_{2}$ & -DE & $\mathrm{D}, \mathrm{E}$ & 1 & 0.3 \\
\hline \multirow[t]{2}{*}{ r" } & -E- & $E$ & 1 & 0.3 \\
\hline & & & 374 & 100 \\
\hline
\end{tabular}

Table 3: Rh Phenotypes of the 374 Pregnant Women in Port Harcourt Metropolis. 


\begin{tabular}{|c|c|c|c|}
\hline $\begin{array}{c}\text { Blood Group } \\
\text { Antigens } \\
\text { Rh }\end{array}$ & $\begin{array}{c}\text { No. of cases of } \\
\text { Neonatal } \\
\text { Jaundice }\end{array}$ & $\begin{array}{c}\text { No. of Blood } \\
\text { Group } \\
\text { Patients }\end{array}$ & $\begin{array}{c}\text { Percentage } \\
\text { (\%) }\end{array}$ \\
\hline RhD've & - & - & \\
\hline RhD-ve $^{\text {tvents }}$ & 36 & 298 & 10.8 \\
\hline C & 8 & 35 & 22.9 \\
\hline C & 7 & 91 & 7.7 \\
\hline E & 39 & 308 & 12.7 \\
\hline e & 9 & 75 & 12.0 \\
\hline
\end{tabular}

Table 4: Distribution of Neonatal Jaundice among blood groups.

\begin{tabular}{|c|c|c|}
\hline Rh gene combination & Number & Percentage \\
\hline cc & 316 & 84.5 \\
\hline Cc & 73 & 19.5 \\
\hline CC & 94 & 25.1 \\
\hline ee & 203 & 54.3 \\
\hline Ee & 52 & 13.9 \\
\hline EE & 74 & 19.8 \\
\hline DD & 341 & 91.2 \\
Dd & 39 & 10.4 \\
\hline dd & & \\
\hline
\end{tabular}

Table 5: Rh antithetical antigens within the study Population.

and Calabar by Jeremiah and Buseri [3] and Jeremiah and Odumody [4] respectively. A pattern of antigens and phenotype frequencies were established whereby the D antigen occurred more frequently than other antigens. In this present study, the Rhesus antigens and phenotype frequencies were studied using the pregnant women as subjects and surprisingly, quite a number of rare and uncommon Rh phenotypes were found to exist in our population. The observed frequencies of $\mathrm{Rh}$ antigens in this study population were as follows: $\mathrm{RhD}(89.0 \%), \mathrm{c}$ (82.0\%), e (54.0\%), C (24.3\%), E (20.1\%), D ${ }^{\mathrm{u}}(0.0 \%)$ and (Kell) K (0.8\%).

This finding was similar to other studies carried out [4-7]. They reported the following frequencies: Caucasians: D (85\%), C (68\%), E (29\%), c (80\%), and e (80\%), Blacks: D (92\%), C (27\%), E (22\%), c (96\%) and e (98\%), Asians: D (99\%), C (93\%), E (39\%), c (47\%), and e (96\%).

The Dccee phenotype was found to be the most common in the population with a frequency of $(25.8 \%)$ and the least DCCEe $(0.3 \%)$. This observation agreed with a similar study carried in Calabar [4]. They reported the following frequencies: Dccee (73.6\%), DccEe (13.9\%), ccee (5.27\%), DccEE (4.44\%), Dccee (1.94\%), DccEe (0.56\%) and Ccee $(0.28 \%)$. We also observed some rare phenotypes among the participants with $\mathrm{RhD}$ deletion frequencies of -c- $(2.9 \%)$, followed by -Ee $(0.5 \%)$, - Cc $(0.3 \%),-\mathrm{C}-(0.3 \%)$ and $-\mathrm{E}-(0.3 \%)$ respectively. It was observed that $-\mathrm{c}$ - had the highest frequency of $(2.9 \%),-\mathrm{Cc}, \mathrm{C}$ and $-\mathrm{E}-$ $(0.3 \%)$ each as least $\mathrm{RhD}$ deletions. In such population there may be a high incidence of HDN, blood transfusion reaction and haemolytic anaemia. This was similar to the finding of Wagner and Flegel [8] the reason is not clear.

D-- or exalted D phenotypes were also observed which demonstrate no Cc or Ee reactivity. This is similar to the finding of Harmening [9]; this was also similar to the findings of Huang et al. [10] Clierif-Zahar et al. [11]. The incidence of blood transfusion reaction, HDN and haemolytic anaemia might be high in such population.

In this study a variety of rare genotype frequencies were also observed as in the case of the phenotypes with $\mathrm{RhD}$ deletions. ---/c-was found to have the highest frequency $(2.9 \%)$, followed by --e/--e
(0.5\%), ---/-Cc (0.3\%), -Cc/-- (0.3\%), and --E/E--(0.3\%) respectively. The highest $\mathrm{Rh}$ probable genotype frequency in the study population was found to be Dce/dce (25.8\%), followed by CD-/--C (18.6\%), cde/ cdE $(0.3 \%)$ and $\mathrm{DcE} / \mathrm{dCe}(0.3 \%)$ respectively. We observed also that some individual within the study population failed to express any of the $\mathrm{Rh}$ antigens on the RBC surface, otherwise known as $\mathrm{Rh}$ null with a frequency of (1.9\%). This agreed with the findings of Avent and Reid [12], on the review of the molecular basis of the Rh blood group phenotype [11]. They all reported that such phenotypes exist in some populations but they did not show any documented evidence.

Exalted (D--) genotype was also observed in the population with a frequency of (4.3\%), this is similar to other studies, [8-14]. There was no statistical data given, but they all reported that such genotypes exist in some populations, especially in the blacks. Such population may have a high incidence of HDN and transfusion reactions. The Rh gene combination was studied also in the population. The following findings were observed: the $\mathrm{DD} / \mathrm{Dd}$ was found to have the frequency of (91.2\%), followed by cc (84.5\%), ee (54.3\%), CC (25.1\%), EE (19.8\%), Cc (19.5\%), Ee (13.9\%) and dd ((10.4\%) respectively. These values obtained were similar in some Rh genes combination and others differ in another study carried out in Port Harcourt and $[3,4]$.

It is pertinent to note that the knowledge of the individual differences in genetic variability as well as their frequency and distribution in a given population is very vital to the understanding of the genetic basis of diseases. As is the case with many $\mathrm{D}$ variants, modified $\mathrm{RhD}$ protein can have important implications for transfusion related antigenicity. The essential clinical difference between Rhesus positive and Rhesus negative hinges on the presence or absence of the $\mathrm{RhD}$ protein in the erythrocyte membrane. Apart from this lack of $\mathrm{RhD}$ protein, the $\mathrm{D}$ negative phenotype could be caused by a series of changes (mutations) in the $\mathrm{RhD}$ protein which in turn change the phenotype of the $\mathrm{D}$ antigen. These changes are classified by partial D, weak D, exalted D or DEL. It is possible that environmental factors occasioned by oil exploration activities in the Niger Delta can lead to such changes which may pose serious health threats to pregnant women. This study was carried out using haemagglutination procedures. Recently, DNA based assays have been used for Rh blood group typing, especially the genotyping for weak and Rh null $[8,10-13]$. However, in this study, molecular typing of the Rhesus RhD gene could not be done to confirm the possible deletions encountered in this serological procedures. It is hoped that our feature research will take care of this. This study was designed to phenotype the red cells for five antigens $(C, D, E, c, e)$ of the Rhesus blood group system. Their corresponding antibodies were therefore not tested. Throughout the period of this study, no patient received Intra-Uterine Transfusion (IUT) as a result of Rhesus incompatibility.

\section{Conclusion}

In conclusion, the findings presented in this study further shows that the Rh blood groups are highly polymorphic in nature. This study concluded as follows: 1) $\mathrm{RhD}$--or exalted $\mathrm{RhD}, \mathrm{Rh}$ deletions and other forms of deletion exist in our typical black population. 2) $R_{\text {hnull }}$ exists in this study population of which similar studies have not been reported in Nigeria. 3) There is need to conduct studies in other parts of Nigeria in order to compare the frequencies of these rare blood groups in Nigerian population. 4) Molecular studies to establish reasons for deletion and $\mathrm{Rh}_{\text {null }}$ phenotypes among Nigerian and Africans in general are hereby advocated. 
Citation: Jeremiah ZA, Biribo AA, Adias TC, Uko EK (2012) Uncommon Rh Phenotypes in a Cross Section of Nigerian Antenatal Women: Implications for Molecular Genotyping of Blood Groups. J Blood Disord Transfus S10:001. doi:10.4172/2155-9864.S10-001

\section{References}

1. Daniels G (2005) The molecular genetics of blood group polymorphism. Transpl Immunol 14: 143-153.

2. Dutta $A B$ (2006) Blood Banking and Transfusion (1stedn), 53-72.

3. Jeremiah ZA, Buseri FI (2003) Rh antigen and phenotype frequencies and probable genotypes for the four main ethnic groups in Port Harcourt, Nigeria. Immunohematology 19: 86-88.

4. Jeremiah ZA, Odumody C (2005) Rh antigens and phenotype frequencies of the Ibibio, Efik, and Ibo ethnic nationalities in Calabar, Nigeria. Immunohematology 21: 21-24.

5. Daniels G (2002) Human Blood Groups. (2ndedn), Blackwell Science, Oxford.

6. Reid ME, Lomas-Francis C (2004) The Blood Group Antigen Facts Books. (2ndedn), Elsevier Academic Press, New York, USA.

7. Race RR, Sanger R (1975) Blood Groups in man. (6thedn) Blackwell Oxford.
8. Wagner FF, Flegel WA (2000) RHD gene deletion occurred in the Rhesus box. Blood 95: 3662-3668.

9. Harmening DM (2005) The Kell (006) and K (019) Blood Group System. Modern Blood Banking and Transfussion Practices. (5thedn), FA Davis Company.

10. Huang $\mathrm{CH}$, Reid ME, Chen $\mathrm{Y}$ (1995) Identification of a partial internal deletion in the RH locus causing the human erythrocyte D--phenotype. Blood 86: 784-790.

11. Chérif-Zahar B, Matassi G, Raynal V, Gane P, Mempel W, et al. (1998) Molecular defects of the RHCE gene in Rh-deficient individuals of the amorph type. Blood 92: 639-646.

12. Avent ND, Reid ME (2000) The Rh blood group system: a review. Blood 95 375-387.

13. Blumenfield OO, Reid ME (2003) Blood group antigen gene mutation database: rare alleles of Rh Loci New York accessed 2003, Huang CH.

14. Flegel WA (2007) The genetics of the Rhesus blood group system. Blood Transfus 5: 50-57.
This article was originally published in a special issue, Immunohematology: Pathogenesis \& Clinical Manifestation handled by Editor(s). Dr. Zaccheaus Awortu Jeremiah, Niger Delta University, Nigeria. 